\title{
Proposal to use time spent chewing as an index of the extent to which diets for ruminants possess the physical property of fibrousness characteristic of roughages
}

\author{
By C. C. BALCH \\ National Institute for Research in Dairying, Shinfield, Reading $R G_{2}{ }_{9} A T$
}

(Received I3 August $1970-$ Accepted 29 March 197 I)

\begin{abstract}
I. Previous publications by the author and his colleagues have provided extensive records of the eating and ruminating behaviour of cows receiving a wide range of diets. These records, and additional unpublished records, have been used to justify a proposed index of the physical property of fibrousness, or roughage, in diets for ruminants.

2. It is proposed that the total time spent by ruminants in chewing their food, during eating and during ruminating, should be the basis of the roughage index.

3. Expression of the roughage index as total time spent chewing per kg dietary dry matter largely eliminates differences resulting from variation in the amount of food consumed, and differences resulting from the time of access to the food.

4. Examples of the proposed roughage index are given. The values range from $\mathrm{I} 45$ to I91 $\mathrm{min} / \mathrm{kg}$ dry matter for oat straw to under $20 \mathrm{~min} / \mathrm{kg}$ dry matter for diets of concentrates or of finely ground herbages; hays and silages tend to fall in the region of $90-110 \mathrm{~min} / \mathrm{kg}$ dry matter. Values for the index increase with increasing dietary proportions of hay or straw.
\end{abstract}

In husbandry, domesticated ruminants receive diets which range from coarse herbages in short supply to highly concentrated mixtures, of cereals and oilcakes, offered $a d$ lib. There has long been debate about the desirability of including in diets for ruminants a proportion of coarse food. Coarse herbages are commonly described as roughages. There is, however, no accepted method of measuring quantitatively the extent to which a given batch of herbage possesses the property of fibrousness characteristic of roughages. Neither has it been possible to describe the extent to which this property is destroyed by mechanical treatment.

Because of this lack of descriptive terms there has been no means of assessing systematically the effects and importance of the property of fibrousness in diets for the different classes of ruminants. The best demonstration of the importance of fibrousness for ruminants is provided by the lactating cow. It was shown by Powell (1939, 1941), and has since been abundantly confirmed, that diets which lack physical fibrousness, either because they contain much concentrate and very little herbage or because they contain a normal proportion of herbage which has been finely ground, cause cows to produce milk of low fat content; further, the triglyceride of milk produced with such diets is abnormally low in short-chain and in saturated fatty acids (Balch, Balch, Bartlett, Cox \& Rowland, r952). It also seems possible that the low fat contents frequently found in the milk of cows receiving young grassland herbage are caused, at least partly, by a lack of physical fibrousness. It is important to know 
whether the physical fibrousness of diets exerts any effect on food utilization in other classes of ruminants.

Demonstration of the effects of almost complete removal of physical fibrousness from diets for, for example, cows does little to show the extent to which this physical property is necessary or desirable. Also, from the experiments which have been carried out, it is not possible to compare individual foods. It would be especially useful to have a means of comparing the extent to which different foods and, more important, different diets possess the physical property of fibrousness.

The need for precise information about the requirement for fibrousness is especially urgent in relation to the pelleting and wafering of dried herbages and the manufacture of pelleted 'complete' diets for ruminants.

The nutritional effects resulting from the presence or absence of roughage in ruminant diets are presumably biochemical in nature, associated with changes in digestion and absorption. The changes appear to be largely associated with alterations in the nature and amounts of the various end-products of digestion.

It is proposed that the total time spent by ruminants in chewing their food, during eating and during ruminating, should be the basis of an index of the extent to which diets for ruminants possess the physical property of fibrousness characteristic of roughages. In this communication I seek to show that this index provides a ready expression of the response of the animal to the physical fibrousness of the food.

Previous publications from this Institute, mainly in this Journal, have given extensive records of the eating and ruminating behaviour of cows receiving various diets. Those records will be used to support the present argument, together with a number of observations not previously published; the method by which the records were obtained is also outlined. The need for an index of the fibrous property of roughages was discussed briefly by Balch (1969).

\section{EXPERIMENTAL}

The values to be discussed have been extracted from experiments described by Balch, Balch, Bartlett, Bartrum, Johnson, Rowland \& Turner (1955), Freer, Campling \& Balch (1962), Freer \& Campling (1965), Campling ( $1966 b$ ) and Campling \& Freer (1966); values have also been summarized from unpublished results of experiments carried out by Dr J. A. Bines.

\section{Cows}

The observations reported were made on dry Shorthorn and Friesian cows. Each cow was fitted with a rumen fistula closed by means of a rubber cannula and bung (Balch \& Cowie, 1962).

\section{Diets and management of the cows}

The diets discussed are indicated in the tables of results; further details will be found in the published papers. Except where discussed below, they were given in restricted amounts which did not permit maximum voluntary intake. 


\section{Recordings and their interpretation}

The time spent chewing during eating and ruminating was determined from records of pressure changes in two small, lightly-inflated balloons, one placed in the reticulum and one held against the jaw. This technique was outlined by Balch, Kelly \& Heim (1951), Balch (1952) and Freer et al. (1962).

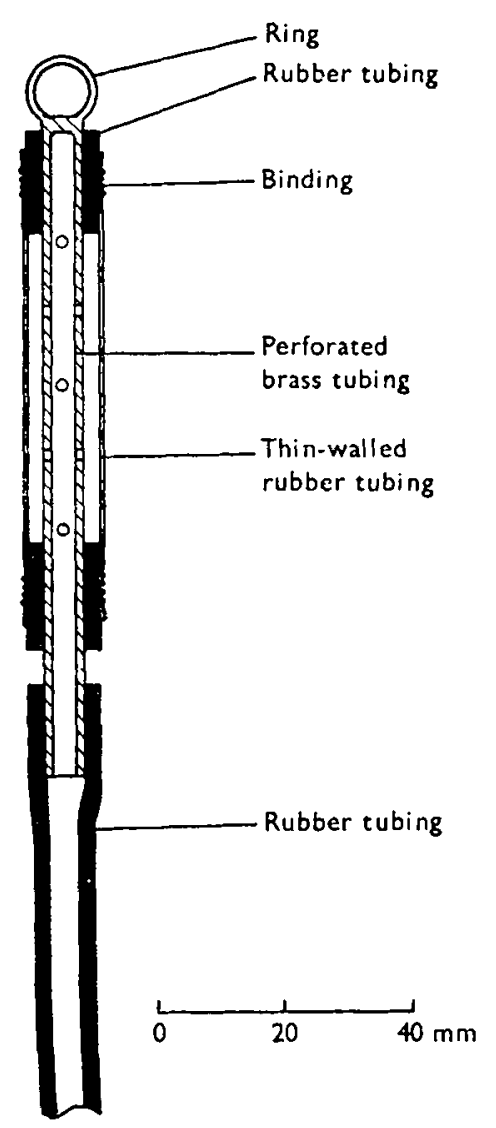

Fig. I. Recording capsule assembly, for determining the time spent by cows in eating or ruminating. Thin-walled rubber tubing is supported on a perforated brass tube to prevent kinking. The assembly is attached by means of the ring. Capsulcs were placed in the reticulum or held against the jaw (see below).

The recording balloons, made of thin rubber tubing, were supported, to prevent kinking, on perforated brass tubes (Fig. I). The reticulum balloons were maintained in position by a rounded brass weight of $\mathrm{I} \mathrm{kg}$; the jaw balloons were fixed beneath the cheek strap of a normal leather head-stall. Changes in pressure in the balloon were recorded by means of physiological tambours set vertically (Balch $e$ t al. 195I).

The records for jaw and reticulum were made in ink on paper $30 \mathrm{~cm}$ wide in an Evershed \& Vignole recorder accommodating up to eight pens (four cows); the recorder was operated at $12.5 \mathrm{~mm} / \mathrm{min}$ over periods of $72 \mathrm{~h}$. Modern electronic 
equipment provides even simpler means of obtaining the same information, but costs are much higher.

A typical record for one cow is shown in Fig. 2. Eating was discerned as a period of continuous jaw movements accompanied by frequent and powerful reticular contractions. Rumination was shown as regular jaw movements with periodical pauses
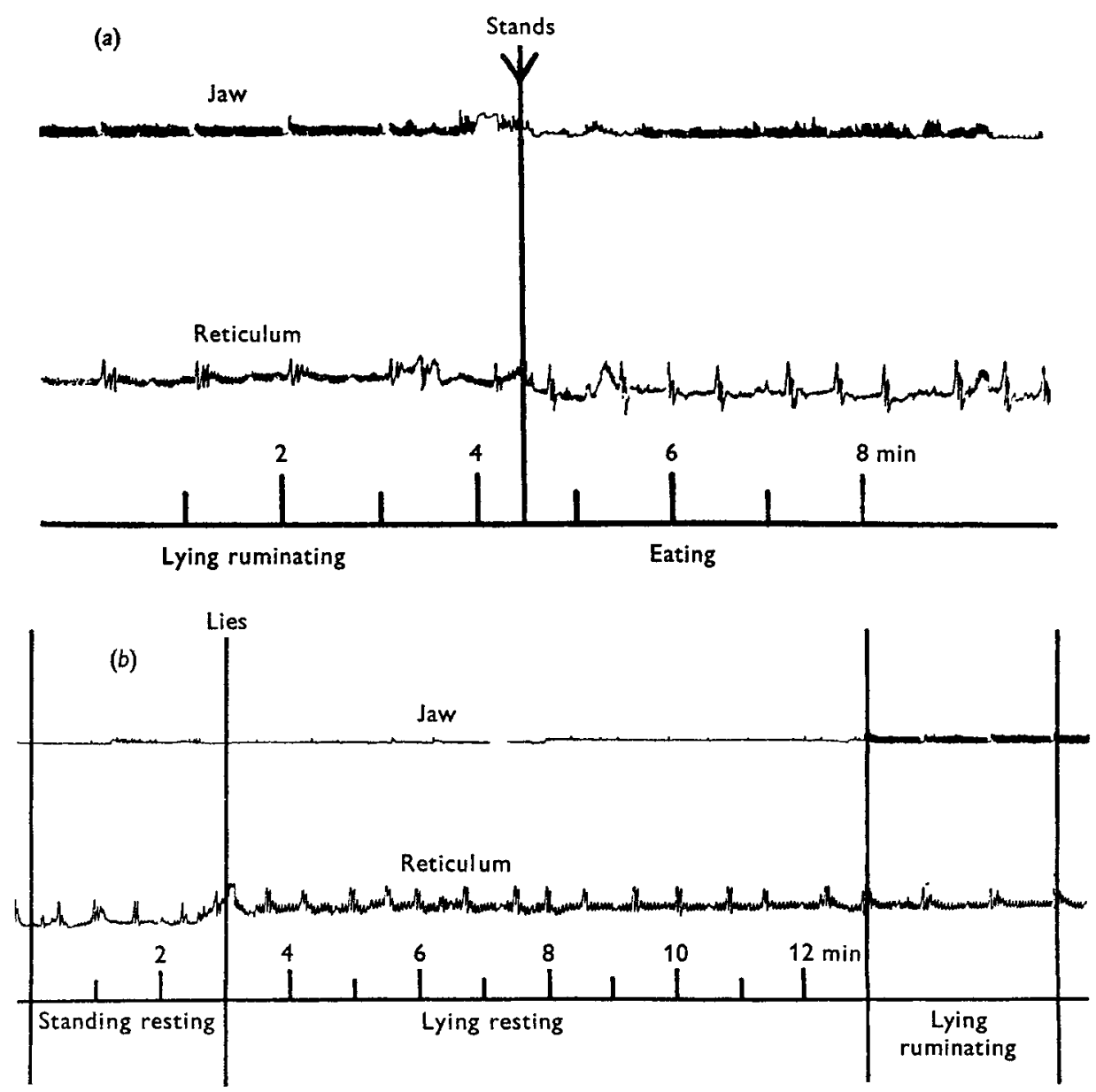

Fig. 2. Two examples of records showing movements of the jaw and pressure changes in the reticulum of a cow. Example (a) shows the change from lying ruminating, with triple reticulum contractions and interrupted chewing, to standing eating, with rapid double reticulum contractions and continuous chewing. Example $(b)$ shows the increase in basal pressure and more regular respiratory movements recorded in the reticulum when a resting cow lies down. The regular jaw movements and triple reticulum contractions of lying ruminating are also shown.

accompanied by triple, as opposed to the normal double, contractions of the reticulum; time spent ruminating was calculated as chewing time plus the pauses while swallowing and regurgitation took place. From these records it was also possible to determine when the animal was standing and lying; during lying the base-line of the reticulum record was elevated and the respiratory movements, recorded between reticular contractions, became more marked and more regular. 
The recording charts provided information about the time spent eating, ruminating or resting (a residual activity) and in standing or lying, in any given period; the number of reticulum contractions occurring in each period was also determined, but this information will not be discussed here.

The charts were spread on a long bench for examination and records were analysed in periods of $24 \mathrm{~h}$.

\section{RESULTS}

Some examples of the times spent by cows in chewing, during eating and ruminating, are given in Table I. Eating occupied $4-60 \mathrm{~min} / \mathrm{kg}$ dry matter, with concentrates and oat straw at the two extremes. True rumination varied from virtually nil with diets of

Table $\mathrm{r}$. Range of values* (min/kg dietary dry matter) for individual cows for the time spent in eating and ruminating when receiving various diets consisting of single foods

(Each value is a mean for periods of $72 \mathrm{~h}$ and each diet was given to three to five cows)

\begin{tabular}{|c|c|c|c|}
\hline Diet & Eating & Ruminating & Total \\
\hline Oat straw & $4 I-58$ & $94^{-1} 33$ & $145-191$ \\
\hline Medium-quality hay & $20-40$ & $63-87$ & $103-109$ \\
\hline Good-quality hay & $27-31$ & $55-74$ & $87-105$ \\
\hline Grass silage & $3 I-58$ & $60-83$ & $99-120$ \\
\hline Dried grass & $8-18$ & $33-39$ & $44-53$ \\
\hline Concentrates $\dagger$ & $4-10$ & $(0-25) t$ & $(4-29$ \\
\hline Finely ground oat straw $\dagger$ & $11-24$ & $(0-20) t$ & $(I x-3 I) f$ \\
\hline Finely ground hay $\dagger$ & I3 & $(0-6) \ddagger$ & $(13-19)$ \\
\hline Finely ground dried grass & $5^{-12}$ & $(0-x I) \ddagger$ & $(5-18) \ddagger$ \\
\hline
\end{tabular}

* The sources are listed on p. 384 .

$\uparrow$ Pelleted.

$\ddagger$ The higher values in the ranges shown in parentheses show the extent of irregular chewing with finely ground diets (see below).

any finely ground food to $133 \mathrm{~min} / \mathrm{kg}$ dry matter with oat straw. True rumination consists of a triple contraction of the reticulum, regurgitation of a 'bolus' of digesta, a period of chewing and the return of the digesta to the rumen. Although some rather irregular triple contractions of the reticulum were seen with finely ground diets (Table I) and there may also be irregular jaw movements with other diets, it is doubtful whether these correspond to true rumination. In any event, acceptance of these irregular movements as evidence of rumination would not invalidate the proposal.

The total time spent chewing, consisting of time spent eating plus time spent ruminating, varied from less than ro $\mathrm{min} / \mathrm{kg}$ dry matter in some cows, receiving diets consisting entirely of concentrates, to I9I min in one cow, receiving oat straw. With hays, the values were 90-I Io min/kg dry matter and, with the grass silage, 100-120 min. Dried grass received approximately half as much chewing as the hays.

In Table 2 are shown values for the amount of chewing observed with cows receiving mixed diets. It is notable that addition of urea, as an intraruminal infusion, 
markedly reduced (Tables $I, 2)$ the time spent chewing oat straw. Increasing the amount of roughage in mixed diets increased the time spent chewing.

Because of the method of collecting results, it is not permissible to determine the significance of difference between values for all the different foods given in Tables I and 2; these are examples of the range of values encountered for individual cows. The tables show, however, that time spent eating, time spent ruminating and total time spent chewing all varied widely between these diets and also between cows receiving the same diet.

Table 2. Range of values* or mean values* (min/kg dietary dry matter) for individual cows for the time spent in eating and ruminating when receiving various mixed diets

(Each value is a mean for periods of $72 \mathrm{~h}$ and each diet was given to two to five cows)

\begin{tabular}{|c|c|c|c|}
\hline Diet & Eating & Ruminating & Total \\
\hline Oat straw + urea & $23-40$ & $67-79$ & $98-\mathbf{I} 17$ \\
\hline Finely ground oat straw + urea & I $5-18$ & $(0-22) \dagger$ & $\left(\right.$ I $\left._{5}-37\right) \dagger$ \\
\hline $\left.\begin{array}{l}\text { Hay + concentrates: } \\
67 \% \ddagger \\
44 \% \\
31 \% \ddagger \\
17 \% \\
8 \% \\
7 \% \\
0 \%\end{array}\right\}$ Hay in diet & $\begin{array}{l}19 \\
18 \\
15 \\
11 \\
21 \\
16 \\
10\end{array}$ & $\begin{array}{r}47 \\
42 \\
37 \\
24 \\
19 \\
20 \\
0\end{array}$ & $\begin{array}{l}66 \\
60 \\
52 \\
35 \\
40 \\
36 \\
10\end{array}$ \\
\hline $\left.\begin{array}{l}\text { Barley straw + concentrates: } \\
60 \% \ddagger \\
40 \% \ddagger \\
20 \% \ddagger \\
0 \%\end{array}\right\}$ Straw in diet & $\begin{array}{l}18 \\
17 \\
16 \\
21\end{array}$ & $\begin{array}{r}44 \\
36 \\
20 \\
0\end{array}$ & $\begin{array}{l}62 \\
53 \\
36 \\
21\end{array}$ \\
\hline
\end{tabular}

* The sources are listed on p. 384 .

$\dagger$ The higher values in the ranges shown in parentheses show the extent of irregular chewing with finely ground diets (see p. 387 ).

$\ddagger$ Pelleted, hay or straw coarsely chopped.

Campling \& Freer (1966) described three experiments which compared the eating time for diets in the long or finely ground states, and Campling (I966 b) described two comparisons between eating times for hays and silages. These were change-over trials of three or four cows each. We can deduce from their tables that the mean residual standard deviation was $2.4 \mathrm{~min} / \mathrm{kg}$ dry matter, and this is a measure of the variation between different occasions for the same cow. Campling (1966b) also gave ruminating times, and we can deduce that the mean residual standard deviation was $3.7 \mathrm{~min} / \mathrm{kg}$ dry matter. These observations suggest that, within change-over trials using three cows, mean differences of $10 \%$ in the roughage index are likely to be meaningful.

\section{DISCUSSION}

The time spent chewing will provide a useful measure of the fibrousness of food only if the time can be expressed in units which are relatively constant for any one diet. It is necessary, therefore, to discuss the reasons for choosing the total chewing time/kg dietary dry matter as this unit. 


\section{Compensatory relationship between eating time and ruminating time}

With most diets the range of values for total chewing time, given in Table $\mathrm{I}$, is smaller than would be expected if eating times and ruminating times varied independently. This suggests a reciprocal relationship between eating time and ruminating time. The existence of such a relationship was demonstrated by Freer \& Campling (1965); when the time of access to hay or straw was restricted, cows ate faster but spent longer ruminating, so that the total time spent chewing, per $\mathrm{kg}$ food, altered little. J. A. Bines \& J. Connell (1970, unpublished) found that in cows receiving artificially dried grass, cut at various stages of growth, the total time spent chewing was consistently less with $5 \mathrm{~h}$ access to food than with $24 \mathrm{~h}$ access; this difference was the result of incomplete compensation in ruminating time for the reduction in eating time.

\section{Frequency of periods of eating and ruminating}

Periods of rumination tend to be spread over the $24 \mathrm{~h}$. Freer et al. (1962) found that the number of periods per $24 \mathrm{~h}$ tends to be relatively constant for any one cow; the numbers ranged from 12 to 24 per $24 \mathrm{~h}$. This characteristic of individual cows is evidently inherited, since the number of periods is closely similar in each sister of monozygotic twins (Campling, I966a).

When given constant access to foods, cows will eat on many occasions during the $24 \mathrm{~h}$. Nevertheless, in cows eating silage in eleven periods or hay in ten periods daily, Campling ( $1966 b)$ could detect no difference in the number of periods of rumination compared to when the same foods were given in single daily periods of $5 \mathrm{~h}$.

\section{Effects of variation in food intake}

In experiments at Shinfield ruminating time and eating time have each been relatively constant, per unit of food, for any one diet; the main exception, as discussed above, has been the increase in ruminating time when the time of access to food was reduced. Some typical values, from Freer et al. (I962) are given in Fig. 3. Hancock (1953) found curvilinear relationships between the amount of two herbages consumed by cows and the time spent ruminating. At any one input, the time spent ruminating was almost twice as long with dried grass containing $29 \%$ crude fibre as with dried grass containing $17.5 \%$ crude fibre. Welch \& Smith (I969a) found more rumination with poor-quality than with good-quality herbages. In sheep, a rectilinear relationship between herbage intake and ruminating time was reported by Welch \& Smith $\left(x_{96} b\right)$; Gordon ( 1965$)$ found, also in sheep, evidence for a complex curvilinear relationship, but it is not clear to what extent there may have been compensatory differences in eating time.

\section{Effects of other foods}

It can be assumed that particles of many foods, other than those usually classed as forages, will need to be chewed during rumination to facilitate passage to the omasum. The effect of adding such foods to forages may be expected, therefore, to exert a direct effect on the amount of rumination. When the extra food contains cereals an 
additional effect may be expected, since it is well known that large amounts of starch delay the fermentation of cellulose in the rumen. Campling (1966a) reported an unpublished observation that alterations in the dietary ratio of hay to concentrates affected the time spent ruminating per $\mathrm{kg}$ hay. From Table 2 it may be calculated that the time spent ruminating per $\mathrm{kg}$ dry matter, as hay or straw, increased as the proportion of hay or straw in the diet decreased. The addition of a concentrate rich in protein may increase the rate of breakdown of cellulose in the rumen. Freer et al. (1962) found that additions of urea to the rumen of cows receiving oat straw decreased the total time spent chewing from 157 to $\mathrm{I}$ IO $\mathrm{min} / \mathrm{kg}$ dry matter.
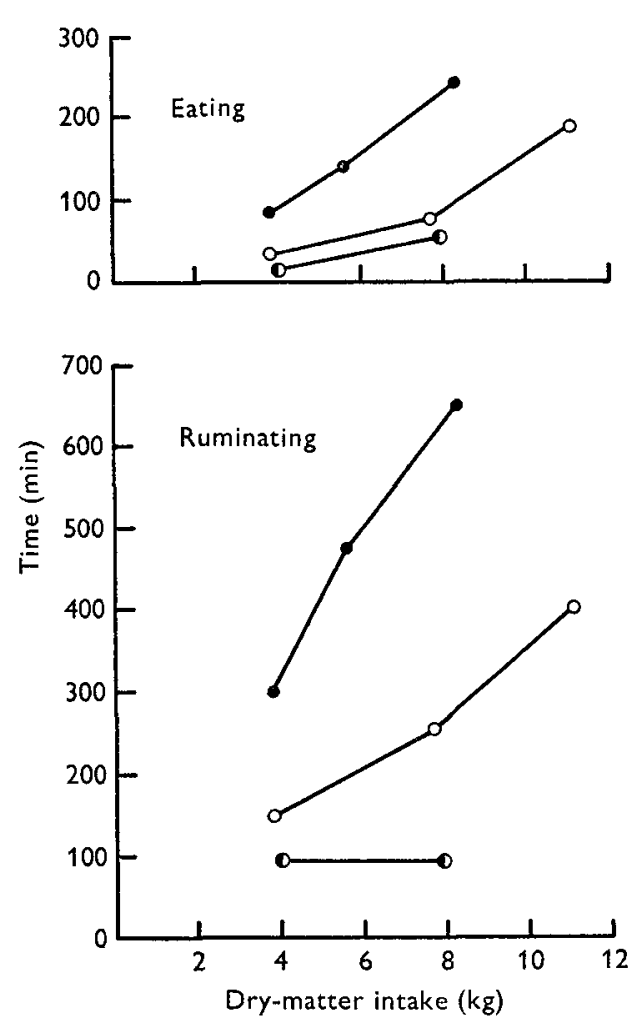

Fig. 3. Time spent daily in eating and ruminating by cows receiving varying daily intakes of hay $(\bullet)$, artificially dried grass $(O)$, or concentrates $(\circlearrowleft)$ (Freer et al. 1962; Freer \& Campling, 1965 ).

\section{Between-individual and between-species differences}

It is to be expected that the amount of work required for chewing, and therefore the time required per $\mathrm{kg}$ food, would vary between individuals and between species. Gill, Campling \& Westgarth (1966) observed differences in the time between cows, and observed protracted chewing times in an old cow which was thought to have had poor teeth. Welch, Gibson \& Smith (I969) have recently observed differences of over roo min in the time spent ruminating per $24 \mathrm{~h}$. In cows of different breeds receiving the same diet, but with concentrates given in proportion to milk yield, it is perhaps 
not surprising that ruminating time also varied according to the amount of milk produced. These differences may best be understood by using an index of the kind proposed below. It is evident, nevertheless, that any statement of an optimum, desirable or even of an undesirable, amount of chewing per $\mathrm{kg}$ dry matter can have relevance only to a limited class of stock.

\section{Conclusion}

From the available observations it appears that the total time spent chewing (eating plus ruminating) is likely to prove more suitable than the time spent eating or ruminating as an index of the physical property of fibrousness. If the total time spent chewing is expressed as min per $\mathrm{kg}$ dietary dry matter, the influence of varying food intakes is largely avoided.

Adoption of the proposed index would provide a means of quantitatively describing a physical property of ruminant diets; this property could then be readily related to the nutritive effect of the diet. It can be calculated, for example, that changing milking cows from diets with a roughage index of 60 to diets with an index of 35 or 40 resulted in marked falls in milk fat content (Balch et al. 1952).

It is not to be expected that the roughage index value of a diet would be the same in sheep and cattle, but it would be surprising if the relative values of different diets were markedly dissimilar. The index provides a useful means of comparing the importance of physical properties of diets in affecting the behaviour of different ruminant species.

Measurements of the roughage index involve recordings of $72 \mathrm{~h}$ duration with a simple recorder. There is undoubtedly a need for a simple laboratory means of assessing the physical properties of diets for ruminants. Troelsen \& Bigsby (1964) described a macerating device for this purpose. The index now proposed provides an animal measurement with which laboratory procedures could be compared.

The ideas in this paper were developed in discussions with Dr R. C. Campling and Dr M. Freer and are based on observations, now largely published, made during their experiments; the discussion has been continued with Dr J. A. Bines, who has kindly agreed to the use of some of his unpublished observations. I am most grateful to these colleagues.

\section{REFERENCES}

Balch, C. C. (1952). Br. F. Nutr. 6, 366.

Balch, C. C. (1969). Proc. Third gen. Mtg Eur. Grassld Fedn, Braunschweig p. 245

Balch, C. C., Balch, D. A., Bartlett, S., Bartrum, M. P., Johnson, V. W., Rowland, S. J. \& Turner, J. (1955). F. Dairy Res. 22, 270.

Balch, C. C., Balch, D. A., Bartlett, S., Cox, C. P. \& Rowland, S. J. (1952). F. Dairy Res. 19, 39.

Balch, C. C. \& Cowie, A. T. (1962). Cornell Vet. 52, 206.

Balch, C. C., Kelly, A. \& Heim, G. (195I). Br. F. Nutr. 5, 207.

Campling, R. C. (1966a). Br. F. Nutr. 20, 25.

Campling, R. C. (1966b). F. Br. Grassld Soc. 21, 41.

Campling, R. C. \& Freer, M. (1966). Br. F. Nutr. 20, 229.

Freer, M. \& Campling, R. C. (1965). Br. F. Nutr. 19, 195.

Freer, M., Campling, R. C. \& Balch, C. C. (1962). Br. F. Nutr. 16, 279. 
Gill, J., Campling, R. C. \& Westgarth, D. R. (r g66). Br. F. Nutr. 20, I 3.

Gordon, J. G. (1965). F. agric. Sci., Camb. 64, 151 .

Hancock, J. (1953). Anim. Breed. Abstr. 21, I.

Powell, E. B. (1939). F. Dairy Sci. 22, 453.

Powell, E. B. (194I). F. Dairy Sci. 24, 504.

Troelsen, J. E. \& Bigsby, F. W. (1964). Y. Anim. Sci. 23, I I 39.

Welch, J. G., Gibson, K. S. \& Smith, A. M. (1969). Y. Dairy Sci. 52, 699.

Welch, J. G. \& Smith, A. M. (1969a). F. Anim. Sci. 28, 813.

Welch, J. G. \& Smith, A. M. (r969b). F. Anim. Sci. 28, 827. 